\title{
Adipose-tissue-specific increase in glyceraldehyde-3-phosphate dehydrogenase activity and mRNA amounts in suckling pre-obese Zucker rats
}

\author{
Effect of weaning
}

Isabelle DUGAIL, Anne QUIGNARD-BOULANGE, Raymond BAZIN, Xavier LE LIEPVRE and Marcelle LAVAU

INSERM U.177, 15 rue de l'Ecole de Médecine, 75270 Paris Cedex 06, France

\begin{abstract}
The regulation of glyceraldehyde-3-phosphate dehydrogenase (GAPDH) gene expression was studied during the onset of obesity in the genetically obese $(f a / f a)$ rat by determination of GAPDH activity and hybridizable mRNA amounts in adipose tissue and liver from suckling and weanling rats. GADPH activity remained low throughout the suckling period, and a burst of activity occurred after weaning in both lean and obese pups. As early as 7 days of age, adipose tissue from pre-obese rats displayed a significant increase in enzyme activity, whereas no difference could be detected in the liver. In both suckling (16 days of age) and weanling ( 30 days of age) obese rats a proportionate increase in GAPDH activity and mRNA amounts was observed in adipose tissue, but not in liver. It is concluded that the obese genotype influences GAPDH gene expression at a pretranslational level and in a tissue-specific manner. This phenomenon could partly contribute to the hyperactive fat accretion in the obese rat, since glycolysis is the major metabolic pathway for lipogenic substrates in adipose tissue.
\end{abstract}

\section{INTRODUCTION}

The genetic obesity of the $f a / f a$ rat, first described by Zucker \& Zucker [1], is due to a single recessive autosomal gene mutation, as yet unidentified. In an attempt to elucidate the nature of the primary lesion, we and others [2-6] have focused our investigations on the pre-obese pups in order to delineate the earliest metabolic changes to occur. We have thus provided evidence that adipose tissue is one of the first sites of expression of the genetic lesion, displaying an increase in key lipogenic enzyme activity within the first week of life $[4,5]$ while no change is detectable in liver. This increased lipogenic capacity is likely to contribute to the hyperactive fat-accretion process that characterizes obese pups. However, the substantial channelling of nutrients into fatty acids suggests the presence in the mutant pups of a concomitant increase in the activity of glycolysis, the main pathway to supply lipogenic substrates. This question, which has never been documented in the pre-obese pup, was addressed here by the study of glyceraldehyde3-phosphate dehydrogenase (GAPDH; EC 1.2.1.12) activity. Although the regulatory role of GAPDH in determining glycolytic flux is not certain in tissues such as brain, muscle or liver, it has been shown that GAPDH is one of the least active glycolytic enzymes in adipose tissue, suggesting that it may exert some control of glycolysis in this tisue [7]. In order to gain insight into the level of regulation of GAPDH activity by the fatty genotype, we examined the content of GAPDH mRNA by hybridization to a specific cDNA probe [8]. These studies were performed in adipose tissue and liver of animals both before and after weaning, since investi- gations of suckling obese pups, which are not yet hyperinsulinaemic [4], are crucial to establish the effect of the fatty genotype independently of hyperinsulinaemia. This study provided an opportunity to document for the first time the developmental regulation of GAPDH gene expression in adipose tissue of rats.

\section{MATERIALS AND METHODS}

\section{Animals and tissues}

Obese $(f a / f a)$ Zucker rats and their lean littermates were bred in our laboratory from pairs originally provided by the Harriet G. Bird Memorial Laboratory, Stow, MA, U.S.A. They were kept at $23 \pm 1{ }^{\circ} \mathrm{C}$ in rooms exposed to light between 07:00 and 19:00 $\mathrm{h}$ and fed on a stock diet containing (w/w) $26.7 \%$ protein, $5.6 \%$ fat, $56.6 \%$ carbohydrate, $14.5 \%$ cellulose and $6.5 \%$ minerals (UAR, Epinay sur Orge, France). Known heterozygous $(F a / f a)$ lean females and obese $(f a / f a)$ males were mated. From this mating, $50 \%$ of the litter is expected to be obese and $50 \%$ lean and of the heterozygous genotype.

Pups had free acçess to the mother's diet and were separated from their, mothers at 28 days of age. Pups were studied at $4,7,11,16$ and 30 days of age in the fed state.

Since there is no rapid way to identify pup genotypes during the first 2 weeks of life, a biopsy of adipose tissue (4-day-old rats) or one whole fat-pad (7- and 11-day-old rats) was removed surgically in order to keep the pups alive for later ( 6 weeks of age) genotype identification. Adipose tissue was used only for GAPDH activity determination in these young pups. At 16 days of age, the 
genotype identification of the pups was made by plotting body weight versus inguinal fat-pad weight as previously described [9]. At 30 days of age, the obese rats were identified on the basis of their inguinal fat-pad weight. At 16 and 30 days of age rats were killed by decapitation; blood from 16-day-old pups was collected for plasma insulin determination. Both subcutaneous inguinal fatpads and liver were removed under sterile conditions and weighed. One half of the liver and the right inguinal fatpad were immediately frozen in liquid $\mathrm{N}_{2}$ for later preparation of RNA; the other half of the tissue was used for GAPDH activity determination.

\section{Enzyme assays}

Tissues were homogenized in ice-cold buffer $(0.25 \mathrm{M}$ sucrose/1 mm-dithiothreitol/1 mM-EDTA, pH 7.4), centrifuged at $105000 \mathrm{~g}$ for $60 \mathrm{~min}$ at $4{ }^{\circ} \mathrm{C}$, and the cytosolic fractions were immediately assayed for GAPDH activity by the method of Wilson et al. [10]. A unit of enzyme activity was expressed as the amount which oxidized $1 \mathrm{nmol}$ of NADH/min at $24^{\circ} \mathrm{C}$. Protein contents were determined by the Bradford [11] assay, with ovalbumin as a standard. Plasma insulin was measured by a radioimmunoassay procedure (kit SORIN CEA).

\section{RNA preparation and Northern-blot analysis}

Total RNA was extracted from tissues by the guanidinium isothiocyanate/ $\mathrm{LiCl}$ procedure described by Cathala et al. [12]. For 30-day-old rats, liver and adipose tissue from each rat were treated separately. For 16-day-old rats, owing to the small amount of adipose tissue, fat-pads from pups of the same genotype were pooled within each litter. RNA content of the sample was determined by the $A_{260}$, and the absence of DNA contamination was checked by electrophoresis on agarose gel and ethidium bromide staining. Total RNA, denatured with $50 \%$ formamide and $2.5 \mathrm{M}$-formaldehyde, was separated by electrophoresis through $1.5 \%$ agarose gel containing $2.2 \mathrm{M}$-formaldehyde in 20 mM-phosphate buffer pH 7.0, and then transferred to a nylon membrane (Hybond-N; Amersham) in $20 \times$ $\mathrm{SSC}(1 \times \mathrm{SSC}: 0.15 \mathrm{M}-\mathrm{NaCl} / 0.015 \mathrm{M}$-sodium citrate $)$. The membranes were exposed to u.v. light for $30 \mathrm{~min}$ and then incubated in prehybridization buffer, containing 0.1 M-sodium phosphate (pH 6.5), $4 \times$ SSC, $5 \times$ Denhardt's solution $(1 \times$ Denhardt's: $10 \mathrm{~g} / 1$ each of Ficoll, polyvinylpyrrolidone and bovine serum albumin), $75 \mu \mathrm{g}$ of heat-denatured salmon sperm DNA $/ \mathrm{ml}, 0.1 \%$ SDS, $1.5 \%$ formamide and $0.1 \% \mathrm{PP}_{\mathrm{i}}$. Prehybridization was performed for at least $2 \mathrm{~h}$ at $42^{\circ} \mathrm{C}$ with gentle shaking. A full-length approx. $1300 \mathrm{bp}$ cDNA probe encoding rat glyceraldehyde dehydrogenase [8], kindly provided by J. M. Blanchard, was labelled by nick translation to a specific radioactivity greater than $10^{8}$ c.p.m. $/ \mu \mathrm{g}$ of DNA, and hybridizations were performed for $16 \mathrm{~h}$ at $42^{\circ} \mathrm{C}$ in prehybridization buffer containing $1 \times$ Denhardt's, $10 \%(\mathrm{w} / \mathrm{v})$ dextran sulphate and the ${ }^{32} \mathrm{P}$-labelled heat-denatured probe $\left(10^{6}\right.$ c.p.m. $\left./ \mathrm{ml}\right)$. After extensive washings in $0.1 \times \mathrm{SSC} / 0.1 \% \mathrm{SDS}$ at $65^{\circ} \mathrm{C}$, the filters were subjected to autoradiography on Kodak XAR films with intensifying screens (Thomson CGR) at $-70^{\circ} \mathrm{C}$. To quantify the difference in GAPDH mRNA amounts between lean and obese rats, blots containing several RNA dilutions were scanned with a densitometer (Cliniscan) equipped with a peak integrator.

\section{Statistical analysis}

Results are expressed as means \pm S.E.M. The level of significance of the differences between groups was calculated either by Student's $t$ test or by a two-way analysis of variance (unweighted means, negligible interaction) described by Snedecor \& Cochran [13].

\section{RESULTS}

In agreement with previous results [3], a slight but significant increase in subcutaneous inguinal fat-pad weight was detected as early as 7 days of age in obese $(\mathrm{fa} / \mathrm{fa})$ pups as compared with lean heterozygous $(\mathrm{Fa} / \mathrm{fa})$ pups $(43 \pm 2.7 \mathrm{mg}$ versus $37 \pm 2 \mathrm{mg} ; P<0.05)$. The overdevelopment of adipose tissue in obese versus lean pups reached $60 \%$ at 11 days of age $(106 \mathrm{mg}$ versus 65 $\mathrm{mg} ; P<0.01)$ and $100 \%$ at 16 days of age $(137 \mathrm{mg}$ versus $80 \mathrm{mg} ; P<0.01)$. At this age, no significant changes in plasma insulin concentrations could be detected between the two genotypes $(34.5 \pm 6.2$ and $44.8 \pm 4.5 \mu \mathrm{units} / \mathrm{ml}$ in lean and obese rats respectively). After weaning ( 30 days of age), adipose tissue in obese rats became massively hypertrophied as compared with lean animals (1036 mg versus $323 \mathrm{mg}$ ). Plasma insulin concentrations were not determined in 30-day-old rats, as hyperinsulinaemia has been consistently observed in obese weaned rats in our $[4,14]$ and other laboratories [1].

The developmental pattern of GAPDH activity in adipose tissue of lean and obese Zucker rats during suckling is depicted in Fig. 1. In lean rats, the activity of GAPDH per $\mathrm{mg}$ of protein declined sharply between 4 and 7 days of age $(P<0.01)$ and remained at a constant low value throughout suckling. In obese pups, GAPDH activity displayed a different developmental pattern in that, after an initial significant decrease $(P<0.05)$ between 4 and 7 days of age, the enzyme activity rose steadily, reaching at 16 days of age a value twice that at 7 days of age. Fig. 1 shows that no difference in GAPDH activity per $\mathrm{mg}$ of protein could be detected between the two genotypes at 4 days of age. A slight but significant difference emerged as early as 7 days of age, and by 16 days of age obese pups had a GAPDH activity nearly 3 times higher than that of lean pups. Owing to the hypertrophied adipose tissue in obese rats, when the results were expressed per total inguinal adipose tissue, the difference in GAPDH activity between the two groups was further enlarged (Fig. 1). Fig. 1 also shows the changes in GAPDH activity in both adipose tissue and liver from day 16 to day 30 , i.e. before and after pups shift from high-fat diet (milk) to high-carbohydrate diet (lab chow). The data show that the dietary and hormonal changes associated with weaning had a marked effect on GAPDH activity in adipose tissue of lean rats, which was increased 3-fold over the pre-weaning values. The effect of weaning was markedly enhanced by the fatty genotype, since a 5-fold increase was then observed from day 16 to day 30. This resulted in GAPDH activity per $\mathrm{mg}$ of protein or per total adipose tissue being 5 or 10 times higher, respectively, in obese than in lean rats. In sharp contrast with adipose tissue, hepatic GAPDH activity underwent no significant changes from suckling to weaning, regardless of the genotype of rats (Fig. 1). In addition, in liver, this enzyme activity was not enhanced by the fatty genotype. It is noteworthy that GAPDH 

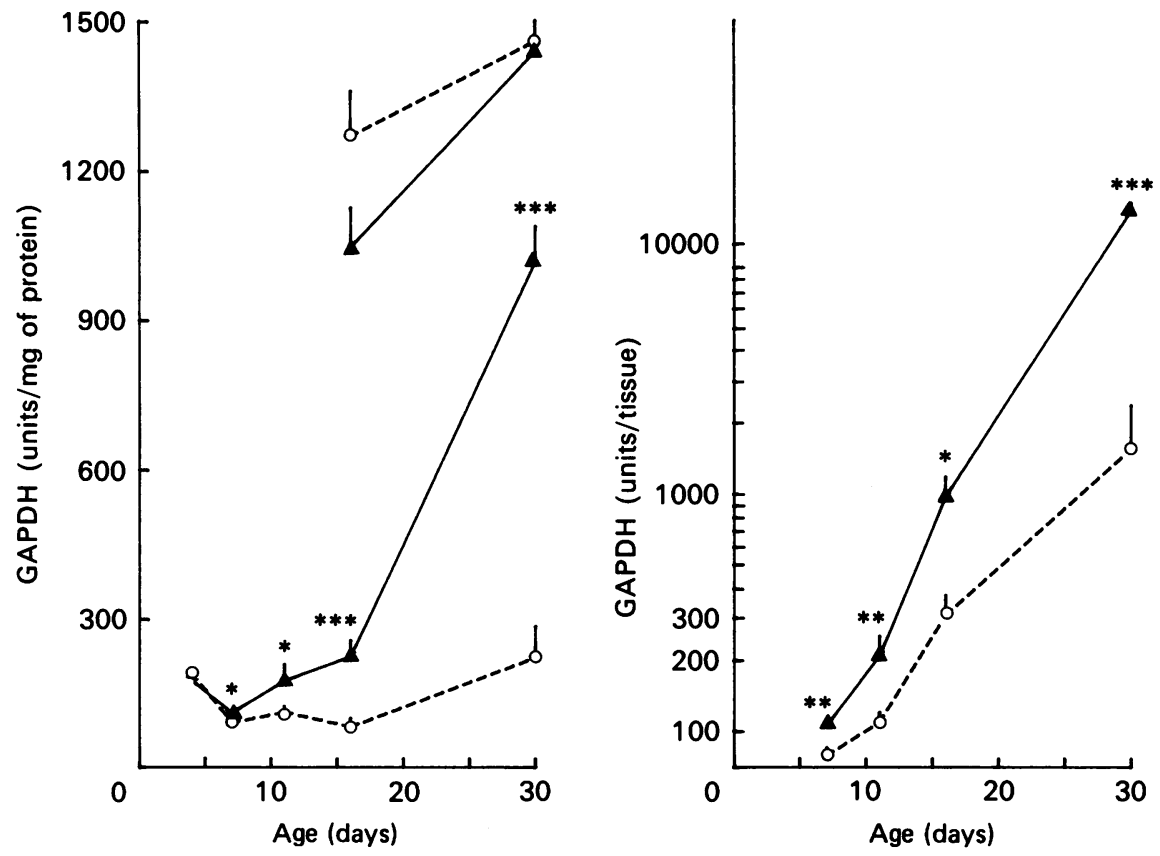

Fig. 1. Evolution of GAPDH activity in adipose tissue and liver from lean and obese Zucker rats

Results are means \pm S.E.M. for 6-19 animals at each data point. Lean rats $(\boldsymbol{\Delta})$ were compared with obese rats $(O)$ by variance analysis: ${ }^{*} P<0.05,{ }^{* *} P<0.01,{ }^{* *} P<0.001$. The upper curves in the left panel represent GAPDH activities in the liver.

Table 1. RNA content of adipose tissue and liver in 16- and 30-day-old lean and obese Zucker rats

Values are means \pm S.E.M. with the numbers of determinations given in parentheses. Adipose tissue from 16-day-old rats was pooled according to the genotype within each litter (three litters were used). Animals were the same as those in Fig. 1. Statistical differences between the two genotypes were assessed by Student's $t$ test: ${ }^{*} P<0.05 ;{ }^{* *} P<0.01$.

\begin{tabular}{|c|c|c|c|c|}
\hline \multirow[b]{3}{*}{ Age of rats } & \multicolumn{4}{|c|}{ Content } \\
\hline & \multicolumn{2}{|c|}{ Adipose tissue } & \multicolumn{2}{|c|}{ Liver } \\
\hline & $(\mu \mathrm{g} /$ fat-pad) & $(\mu \mathrm{g} / \mathrm{g}$ of tissue) & ( $\mu \mathrm{g} /$ liver) & $(\mu \mathrm{g} / \mathrm{g}$ of liver) \\
\hline \multicolumn{5}{|l|}{16 days } \\
\hline $\begin{array}{l}\text { Lean } \\
\text { Obese }\end{array}$ & $\begin{array}{l}63 \pm 23(3) \\
79 \pm 23(3)\end{array}$ & $\begin{array}{l}770 \pm 138(3) \\
596 \pm 139(3)\end{array}$ & $\begin{array}{l}3660 \pm 230(7) \\
3660 \pm 218(10)\end{array}$ & $\begin{array}{l}5750 \pm 359(7) \\
5505 \pm 327(10)\end{array}$ \\
\hline \multicolumn{5}{|l|}{30 days } \\
\hline $\begin{array}{l}\text { Lean } \\
\text { Obese }\end{array}$ & $\begin{array}{l}157 \pm 22(9) \\
251 \pm 24(11)^{*}\end{array}$ & $\begin{array}{ll}499 \pm 75 & (9) \\
244 \pm 15 & (11)^{* *}\end{array}$ & $\begin{array}{l}11430 \pm 730(6) \\
14140 \pm 810(7)^{*}\end{array}$ & $\begin{array}{l}5200 \pm 330(6) \\
4200 \pm 240(7)^{*}\end{array}$ \\
\hline
\end{tabular}

activity per mg of protein was substantially higher in liver than in adipose tissue.

In order to gain some insight into the level at which the fatty genotype regulates GAPDH, we measured the relative content of GAPDH hybridizable mRNA in total RNA isolated from tissues of obese and lean rats. The two genotypes were compared before (16 days of age) and after (30 days of age) the emergence of hyperinsulinaemia. At 16 days of age, no difference in the amount of total RNA could be detected between the two genotypes in either adipose tissue or liver (Table 1). Northern-blot analysis (Figs. 2 and 3) showed that the rat muscle GAPDH cDNA probe used in this study recognized a unique rat mRNA with an approximate size of $1.3 \mathrm{~kb}$ in both adipose tissue and liver. Fig. 2 demonstrates that adipose tissue from 16-day-old obese pups had higher GAPDH mRNA contents than did adipose tissue from lean pups (lanes $B$ and $D$ versus lanes $A$ and ); equivalent signals were obtained with $40 \mu \mathrm{g}$ of RNA from lean rats and $13 \mu \mathrm{g}$ of RNA from obese rats (lanes I and L). These data, confirmed by densitometric analysis, revealed that the 3-fold induction in GAPDH mRNA in adipose tissue of obese compared with lean pups was roughly proportional to the changes in total adipose-tissue GAPDH activity (Fig. 1). Moreover, the hybridization of the same blots with a cDNA probe that recognizes a subunit of cytochrome oxidase mRNA [15] showed no difference between the two genotypes (Fig. 2), supporting the conclusion of a specific increase in GAPDH mRNA in the suckling-obese-rat adipose tissue.

Northern blots of adipose-tissue RNA obtained from 


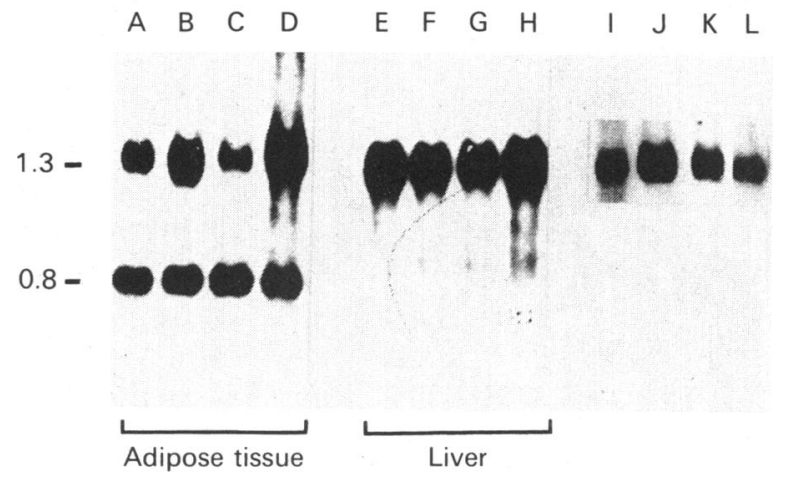

Fig. 2. Northern-blot analysis of RNA from 16-day-old lean and obese Zucker rats

Samples $(40 \mu \mathrm{g})$ of RNA from adipose tissue and liver isolated from lean (lanes $\mathrm{A}, \mathrm{C}, \mathrm{E}, \mathrm{G}$ ) and obese (lanes B, $\mathrm{D}, \mathrm{F}, \mathrm{H})$ rats were run and probed with a GAPDH cDNA, which hybridized with a $1.3 \mathrm{~kb}$ mRNA, as described in the Materials and methods section. In adipose tissue, the intensity of signals obtained with $40 \mu \mathrm{g}$ of RNA from lean rats (lane I) was compared with those from $40 \mu \mathrm{g}$ (lane J), $20 \mu \mathrm{g}$ (lane $\mathrm{K}$ ) and $13 \mu \mathrm{g}$ (lane L) of RNA from obese animals. After hybridization with the GAPDH cDNA, the blot (lanes A-D) was re-probed with a cDNA encoding the third subunit of cytochrome $c$ oxidase (pIL7), which recognizes a unique $0.8 \mathrm{~kb}$ mRNA [15]. Molecular sizes (in $\mathrm{kb})$ of GAPDH mRNA and cytochrome $c$ oxidase mRNA are shown on the left.

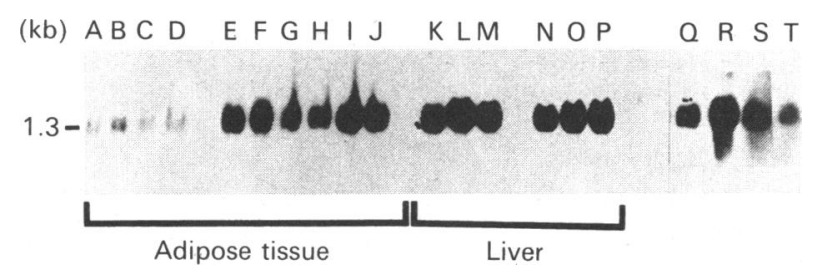

Fig. 3. Northern-blot analysis of RNA from 30-day-old rats

Samples $(40 \mu \mathrm{g})$ of RNA from adipose tissue and liver were isolated from lean (lanes A-D and $\mathrm{K}-\mathrm{M}$ ) and obese (lanes E-J and N-P) rats as described in the text. The signals obtained with RNA from a lean rat ( $40 \mu \mathrm{g}$, lane $\mathrm{Q})$ were compared with those from $40 \mu \mathrm{g}$ (lane R), $13 \mu \mathrm{g}$ (lane S) and $5 \mu \mathrm{g}$ (lane T) of RNA from an obese rat. The molecular size of GAPDH mRNA is shown on the left.

30-day-old lean and obese Zucker rats are shown in Fig. 3. At this age, the hybridization signals per $\mu \mathrm{g}$ of RNA were 5 times greater in obese than in lean rats. Therefore it can be estimated that, given the 1.6-fold increase in the amount of RNA per tissue observed in obese rats (Table 1), the amount of GAPDH mRNA per tissue was approx. 8-fold greater in obese than in lean rats, in close proportion to the changes in total adipose-tissue GAPDH activity observed between the two genotypes (Fig. 1). In contrast, in liver, it is clear that GAPDH mRNA amounts were not modified by the fatty genotype in either 16-day-old or 30-day-old rats (Figs. 2 and 3 ).

\section{DISCUSSION}

The regulation of GAPDH activity in adipose tissue is poorly documented. This study demonstrates that adipose-tissue GAPDH in lean Zucker rats is modulated by developmental factors and, over the suckling and weaning periods, displays a pattern of changes similar to the profile previously described in the same rats for lipogenesis-related enzymes [4]. However, GAPDH is distinguished from these enzymes in that its response to weaning is much lower (about a 3-fold increase) than that of adipose-tissue lipogenic enzymes (at least a 12fold increase) [4]. In liver also, GAPDH is distinguished from lipogenesis-related enzymes, which have been shown to increase several-fold in liver of lean Zucker rats from 16 days to 30 days of age [4]. Our data point out the tissue-specificity of the developmental and/or dietary regulation of GAPDH, with the remarkable stability of liver GAPDH activity in response to weaning.

The purpose of the present study was to determine whether the fatty genotype regulates GAPDH activity in these tissues and to specify the level of its control. Our data on post-weaning 30-day-old rats, in agreement with previous results on adult Zucker rats [16], demonstrate that GAPDH activity is altered in fatty rats in a tissuespecific manner, since adipose tissue exhibits a dramatic increase in enzyme activity, but no change is detected in liver. Moreover, the present study shows a marked increase in adipose-tissue GAPDH mRNA content in fatty rats that is proportional to the increase in GAPDH activity. The observation of an increase in GAPDH mRNA in adipose tissue from 30-day-old obese rats, whose hyperinsulinaemia has been reported to be approx. $150 \mu \mathrm{units} / \mathrm{ml}$, compared with $25 \mu \mathrm{units} / \mathrm{ml}$ in lean [14], is in line with the finding by Alexander et al. [17] that the amount of GAPDH mRNA in 3T3LI and 3T3F442A cultured adipocytes was regulated by insulin in a dosedependent manner.

The study of 16-day-old suckling pups enabled us to establish the stimulatory effect of the fatty genotype on GAPDH gene expression in adipose tissue independently of hyperinsulinaemia, as increases in GAPDH activity were mediated at this age also through proportional changes in mRNA amount. Therefore, in the mutant fatty rat, the control of GAPDH gene expression is exerted at a pretranslational level both before and after the emergence of hyperinsulinaemia. Recent reports have demonstrated that the regulation of GAPDH gene expression could be exerted at both transcriptional [18] and post-transcriptional [19] levels. However, the molecular mechanism for the increase in GAPDH mRNA in adipose tissue of obese rats, i.e. changes in the rate of specific gene transcription, or in the stability of the mature RNA, could not be documented, owing to the limited amount of tissue. We have disclosed that the increase in GAPDH activity is an early feature of adipose tissue in fatty rats, detectable by 7 days of age, but not yet present at 4 days of age. This suggests that the ability of genotype to modify GAPDH activity requires prior developmental changes. One of them could be the accumulation of GAPDH mRNA, and the temporal relationship between mRNA amount and GAPDH activity in the adipose tissue of fatty newborns deserves to be investigated. A further question to be addressed is the etiological role of this early induction in GAPDH activity. It could contribute to increasing the glycolytic flux in adipose tissue, and the supply of substrates for lipogenesis.

In conclusion, our work shows that GAPDH is part of a subset of enzymes, including fatty acid synthetase and 
lipoprotein lipase $[3,5,20]$, which are specifically induced in adipose tissue by the fatty genotype within the first week of life, and before the development of hyperinsulinaemia. How proximal these alterations are to the genetic lesion is one of the challenging questions that remain to be elucidated.

We are very grateful to J. M. Blanchard (Montpellier, France) and to N. Glaichenhaus (Nice, France) for kindly giving us pRGAPDH 13 clone and cytochrome oxydase (pIL7) cDNA respectively, to D. Ricquier and F. Bouillaud (Meudon, France) for their expert advice and instruction on Northernblot analysis techniques, to F. Dupuy for skilful technical assistance, and to $\mathrm{V}$. Resve for typing the manuscript.

\section{REFERENCES}

1. Zucker, L. M. \& Zucker, T. F. (1961) J. Hered. 62, 275-278

2. Godbole, V., York, D. A. \& Bloxham, D. P. (1978) Diabetologia 16, 41-44

3. Boulange, A., Planche, E. \& de Gasquet, P. (1979) J. Lipid Res. 20, 857-864

4. Bazin, R. \& Lavau, M. (1982) J. Lipid Res. 23, 839-849

5. Lavau, M., Bazin, R. \& Guerre-Millo, M. (1985) Int. J. Obesity 9, 61-66

6. Planche, A., Joliff, M., de Gasquet, P. \& Le Liepvre, X. (1983) Am. J. Physiol. 245, E107-E113

Received 19 January 1988/18 April 1988; accepted 25 April 1988
7. Harris, J. I. \& Waters, M. (1976) Enzymes 3rd Ed. 13, $1-49$

8. Fort, Ph., Marty, L., Piechaczyk, M., El Sabrouty, S., Dani, Ch., Jeanteur, Ph. \& Blanchard, J. M. (1985) Nucleic Acids Res. 13, 1431-1442

9. Lavau, M. \& Bazin, R. (1982) J. Lipid Res. 23, 941-943

10. Wilson, J. H. E., Reid, S. \& Masters, C. J. (1982) Arch. Biochem. Biophys. 215, 610-620

11. Bradford, M. M. (1976) Anal. Biochem. 72, 248-254

12. Cathala, G., Savouret, J. F., Mendez, B., West, B. L., Karin, M., Martial, J. A. \& Baxter, J. D. (1983) DNA 2, 329-335

13. Snedecor, G. W. \& Cochran, W. G. (1967) Statistical Methods, 6th edn., pp. 472-477, Iowa State University Press, Ames, IA

14. Krief, S., Bazin, R., Dupuy, F. \& Lavau, M. (1988). Am. J. Physiol. 254, E342-E348

15. Glaichenhaus, N., Leopold, P. \& Cuzin, F. (1986) EMBO J. 5, 1261-1265

16. Spydevold, S. O., Greenbaum, A. L., Baquer, N. Z. \& MacLean, P. (1978) Eur. J. Biochem. 89, 329-339

17. Alexander, M., Curtis, G., Auruch, J. \& Goodman, H. M. (1985) J. Biol. Chem. 260, 11978-11985

18. Alexander-Bridges, M. (1987) Diabetes 36 (Suppl. 1), 8A (abstr.)

19. Piechaczyk, M., Blanchard, J. M., Marty, L., Dani, Ch., Panabieres, F., El Sabouty, S., Fort, P. \& Jeanteur, P. (1984) Nucleic Acids Res. 12, 6951-6963

20. Dugail, I., Quignard-Boulange, A., Brigant, L., Etienne, J., Noe, L. \& Lavau, M. (1988) Biochem. J. 249, 45-49 